\title{
Pure pedagogy: educational tools to maintain student interest and engagement in language courses
}

Garrett Fisher ${ }^{1}$, Universidad de Carolina del Oeste, Estados Unidos de Norteamérica

Recibido: 23 marzo de 2017.

Aprobado: 27 mayo de 2017.

\begin{abstract}
In 2017, language educators are considering the best ways to educate students because of the increase in technology use. This article addresses three topics that language instructors frequently consider: (1) the use of technology with current students, (2) appropriate methods and technologies for use with current generations, and (3) the implementation of change to increase student engagement. This article argues that engagement is a critical aspect in language classrooms and knowledge of current students, technology, and second language teaching methods can help maintain interest and participation with students. While it is futile to argue for a single method as the most optimal way to teach a language, this paper offers information on multiple methods and evaluates their usage with current generations while touching on the considerations that must be taken into account while implementing technology with students in language classrooms. This research utilizes Task-Based Language Teaching (TBLT) as a main base for the methodological framework, yet other methods are considered because technology and additional methods, such as the Grammar-Translation Method, the Natural Method, Community Language Learning (CLL), Total Physical Response (TPR), and Teaching Proficiency through Reading and Storytelling (TPRS) can be integrated within TBLT to maintain the interest and engagement of current language students.
\end{abstract}

\section{Resumen}

\section{Pedagogía Pura: Herramientas Educativas para mantener el Interés y la participación activa en Cursos de Idiomas}

En 2017, los educadores de idiomas están poniendo en consideración las mejores maneras de educar a los estudiantes debido al aumento del uso de la tecnología. Este artículo aborda tres temas que los instructores en idiomas a menudo ponen bajo consideración: (1) El uso de la tecnología con los estudiantes actuales, (2) los métodos y tecnologías apropiadas para usarse con las generaciones actuales y (3) la implementación del cambio para aumentar el engagement (compromiso) de los estudiantes. Este artículo propone que el engagement es un aspecto crítico en las aulas de idiomas y el conocimiento de los estudiantes actuales, la tecnología, y los métodos de enseñanza de idiomas pueden mantener el interés y la participación de los estudiantes. A la vez es inútil argüir que un solo método de enseñanza es el óptimo para enseñar un idioma. Este artículo brinda información de múltiplos métodos y su uso con las generaciones actuales y al mismo tiempo trata lo que se considera que se debe tomar en cuenta al implementar la tecnología con estudiantes de clases de idiomas. Esta investigación utiliza el Task-Based Language Teaching (TBLT) como base principal del marco teórico, a pesar de que otros métodos se toman en cuenta (la tecnología y métodos adicionales), tales como GrammarTranslation Method, the Natural Method, Comunity Language Learning (CLL), Total Physical Response, y Teaching Proficiency through Reading and Storytelling (TPRS) se pueden integrar con el TBLT para mantener el interés y el engagement de los estudiantes de idiomas actuales.

1 Garrett Fisher es Máster de las Artes en Español, graduado de la Universidad de Carolina del Norte, y doctorando en Educación en Liderazgo Educativo, por la Universidad de Nueva Inglaterra, Estados Unidos. Labora como docente en el departamento de Lenguas del Mundo de la Universidad Carolina del Oeste. Contacto: gdfisher@wcu.edu.
Garrett Fisher. Pure Pedagogy: Educational tools to maintain student interest and engagement in language courses. Revista Comunicación. Año 38, volumen 26, número 1, enero - junio, 2017. Instituto Tecnológico de Costa Rica. ISSN: 0379-3974 / e-ISSN: 1659-3820.

\section{KEY WORDS:}

Technology, TPRS, TBLT, Generations, Second Language Teaching, Languages, Engagement, Generation Y, Generation Z.

PALABRAS CLAVE:

Tecnología, TPRS, TBLT, Generaciones, Enseñanza de un Segundo Idioma, Idiomas, participación activa, Generación Y, Generación Z. 
Educational leaders constantly question efficiency and investigate new ideas and ways to foster growth and improvement. According to Koulopoulos and Keldsen (2014), "If you accept that education is that important, then you must also accept that, as the world changes, it is critical to understand just how dramatic the changes to educational approaches can and will be" (p. 133). An effective educator is one who desires to constantly learn and understand more about the subject he teaches and the students he leads. Burns (1978) stressed that leadership is a relationship encompassing both a leader and a follower; both parties should be considered. Educators must analyze the methods and material that allow them to teach, but also their target audience: the students. This academic work considers technology, students in 2017, methods for teaching languages, and institutional change to review possibilities and support for language educators to understand how to maintain interest and engagement with current students in language classrooms. It is argued here that engagement is a critical aspect in language classrooms and knowledge of current students, technology, and second language teaching methods can help maintain interest and participation with students. University students are primarily considered here, yet some of the discussion may help K-12 language educators.

Through the consideration of numerous sources, the following questions were sought to be answered:

1. Should technology be used with language students in 2017?

2. Which methods and technologies are appropriate for Generation Y and Z?

3. How can change be implemented to increase engagement and participation with Generation $\mathrm{Y}$ and $\mathrm{Z}$ ?

\section{METHODOLOGICAL FRAMEWORK AND ITS CONNECTION TO CURRENT LANGUAGE STUDENTS}

This research utilizes Task-Based Language Teaching (TBLT) as a main base for the methodological framework, yet other methods are considered because technology and additional methods, such as the Grammar-Translation Method, the Natural
Method, Community Language Learning (CLL), Total Physical Response (TPR), and Teaching Proficiency through Reading and Storytelling (TPRS) can be integrated within TBLT to maintain the interest and engagement of current language students.

Task-Based Language Teaching focuses on the student using tasks to facilitate language learning. González-Loret (2015) explained how TBLT can be used while taking "...advantage of a new era of learners who are comfortable with innovation and integrates the learning of language and new digital, communicative, and multimedia literacies, all under the philosophy of "learning by doing". This concept is not necessarily new, as James Asher's Total Physical Response method encouraged kinesthetic learning, yet TBLT simulates real-life situations instead of focusing on language commands. TBLT does not necessarily require technology; however, according to González-Loret (2015), "Adding technology to a curriculum brings a whole new set of real-world tasks, which should also become target tasks and part of the curriculum" (p. 6). For example, planning a family vacation to Mexico in 2017 does not necessarily require verbal communication. Technology now allows us to research areas and make reservations online, but we must understand and know how to use the tools to get to our destination. It is imperative that we come to terms with the reality of how our students will use their language skills and encourage their learning in ways that they feel comfortable. Language educators commonly teach students how to look up a word in a dictionary, yet when our current students go home, they use the Internet to look up words because it is a faster process. We know that our time in the classroom is limited, so using an electronic device to look up a word in class may afford more time practicing the language. Furthermore, students will not always carry a paper dictionary with them on a daily basis, but our current students generally do not go anywhere without a cellphone.

TBLT focuses on the needs and wants of the students (González-Loret, 2015). How do our students really want to use the language? We must consider their activities that involve language.

Examples of real-life situations:

- Planning vacations. 
- Writing an email/text messages.

- Asking someone for directions.

- Ordering food in a restaurant.

- Employing general questions for small-talk.

- Commanding someone to complete a task.

- Utilizing short phrases for video games.

Students will not be conjugating verbs on a worksheet while asking for directions in Costa Rica, so why do educators use this practice so frequently in language classrooms? Indeed, the reasoning behind understanding verb conjugations is to learn rules to later apply to new situations; however, processing the rules for conjugations and then selecting one option from multiple choices takes longer than regurgitating a simple learned phrase.

\section{THE DECISION TO EMBRACE OR SHUN TECHNOLOGY IN LANGUAGE COURSES}

Should technology be used with language students in 2017? Technology is a topic of interest for educational institutions because of many reasons, yet it is common to find two extreme opinions on technology implementation in courses. While some language instructors struggle to teach without technology, others prefer to rid classrooms of any trace of it. Researchers have evaluated technology implementation in the past and the results lean towards the use of it. Grgurović, Chapelle, and Shelley (2013) analyzed the effectiveness of language pedagogies with technology in contrast with language pedagogies without technology by considering empirical research, which included 85 studies from 1970-2006 and found that language instruction with technology was as effective as language instruction without technology. This provides evidence that technology can be beneficial in language classrooms and supports educators who have an interest in implementing technology to maintain the interest and increase engagement with current students.

Collins and Halverson (2009) considered both sides of technology implementation by first explaining that a major benefit of technology is the ability to cater to specific needs and provide individualized attention while offering an opportunity for scaffolding. Scaffolding is common in pedagogy, as, according to Lantolf and Appel (1994), it is the support given to a student to accomplish a specific task that would normally be difficult without help. Collins and Halverson (2009) went on to explain the skeptic's view of technology, arguing that technology encourages commercial media, comes with an exorbitant price tag, and discourages human interaction. While this perspective may be valid, technology is now a common tool for societal interactions, traveling, reading, working, and learning. According to Collins and Halverson (2009), "Technology is moving education out of schools and into homes and workplaces, preschools and post-schools, after hours and after-afterhours" (p. 6).

Liu, Lan, and Jenkins (2014) found that multiple online tools enhance and increase the interest of the learner. Generation Z students appreciate being constantly connected to the internet and become uncomfortable when they do not have the ability to connect. According to a 2012 study by JWT, a communication marketing brand, $86 \%$ of U.S. participants age 13-17 said they would be upset if they had to give up the connection to the internet and $78 \%$ said they would be upset if they had to give up their cell phone. This specific generation expects to be able to connect and to avoid technology use in the classroom could upset them and potentially interfere with language acquisition.

According to Thorne \& Smith (2011), the question of whether or not technology should be used in the classroom has now changed to how it should be used. Technology in the 1990s meant having a computer with a black and white screen or a large television on a rolling cart. Technology in the early 2000s meant having a lab of computers with color screens and utilizing PowerPoint. Technology in the present day (2010s) includes cellphones with applications, online software, projectors, document cameras, tablets, interactive boards, and additional devices. We have the technology and the students are craving it, but we must decide how to best use our resources without causing distractions. If a language educator decides to use technology in a course, the following questions must be considered:

1. Why should a specific technology be used? 
2. Which technology should be used?

3. Should the technology be used in class or in another location?

4. What are the advantages/disadvantages of using a specific technology?

5. What rules or guidelines are necessary for this technology?

6. How can student learning be assessed with the technology?

7. What resources are available for troubleshooting and planning?

The previous seven questions are meant to guide educators in making decisions while considering the adoption of technology in a language classroom. While this paper supports the use of technology, a technology skeptic may find it useful to ponder the seven questions to evaluate the usefulness of a specific technology, as it may provide a rationale for the technology utilization.

As previously mentioned, studies indicate that technology can enhance the learning experience and students are upset when they are not allowed to use technology. Before making a decision to embrace or shun technology, it is also important to consider the audience: the students of 2017.

\section{WHO ARE THE LANGUAGE STUDENTS IN 2017?}

As previously discussed, language educators make the choice to plug or unplug during an academic semester. If the majority of the students in a course utilize technology on a daily basis, is it wise for an instructor to avoid technology? Prensky (2001) described the students of the latest generation as "digital natives" because of their obsession with technology and later explains the need for a change in education to fit their needs. Tulgan, Baumann, Graham and McDonald (2016) compared the generations that could be present in classrooms today, including the Baby Boomers born 19461964, Generation X born 1965-1977, Generation Y born 1978-1989, and Generation Z born 1990-1999. While the analysis of Tulgan, Baumann, Graham and McDonald (2016) focused on highlighting Generation Z, it is helpful to understand that each generation is different and variances are noticed in behavior, training, styles of learning and communication, problem-solving methods, and decision-making skills and leadership style. The majority of university undergraduate students in the U.S. fall into the category of Generation Z.

According to a 2013 study, $88 \%$ of full-time enrolled undergraduate students at 4-year public institutions were under 25 and $73 \%$ of full-time enrolled undergraduates at 2-year public institutions were under 25 (National Center for Education Statistics, 2013). Generation $Y$ accounts for $9 \%$ of full-time enrolled undergraduate students at 4-year public institutions and $16 \%$ at 2-year public institutions (National Center for Education Statistics, 2013). Although these two generations are close in age, they are not identical. Tulgan, Baumann, Graham and McDonald (2016) explained that while Generation $Y$ students prefer to have feedback on demand, Generation Z students enjoy having consistent and frequent feedback. Tulgan, Baumann, Graham and McDonald (2016) highlighted that the learning style of Generation Z is technology-based, whereas the Generation $\mathrm{Y}$ learning style is collaborative and networked.

As educators, it is essential to inspire and encourage students to be leaders, but generations can have common leadership styles. Tulgan, Baumann, Graham and McDonald (2016) pointed out that Generation $Y$ students prefer to lead with partners, while Generation Z students prefer to lead by teaching. With or without technology, this generational information is helpful to the language educator to understand how each generation learns and interacts.

\section{WHAT ARE THE WEAKNESSES OF LANGUAGE STUDENTS IN 2017?}

Generation Z may be able to learn about new technology quickly, but what may be a potential weakness with second language acquisition? Tulgan, Baumann, Graham and McDonald (2016) mentioned, "Although this generation adopts new technology with ease, Gen Z has been criticized for having poor writing skills" (p. 9). Orthography is an area in which these particular students may need special attention, as texting and the use of social media commonly encourage shortening messages 
to even a few letters. Students now have the ability to express an emotion without ever writing or typing anything by opting to use an emoji. Speed is important to Generation Z students. Facebook realized this and made a change in the way users can post by adding an emoji option. Chaykowski (2016) pointed out, "Facebook said it wanted to give users more authentic ways to quickly and easily respond to posts, whether they are sad, serious, funny or happy" (par. 3). While this could indicate that the language students of 2017 may not enjoy verbal conversation in courses, resulting in a conversational weakness, it is important to examine other habits of Generation $Y$ and Z. Video blogging is of interest to these two generations and this is evident while perusing YouTube channels and Vine clips. Both generations enjoy self-expression and comedic entertainment through input and innovation. While one could speculate that another weakness could be found in spending too much time with technology, as it could be detrimental to relationship building and career preparation, companies are now searching for youth who are adept in social media marketing techniques.

\section{EVALUATING 5 LANGUAGE TEACHING METHODS FOR USE WITH GENERATION Y AND Z}

After acknowledging that most students in 2017 are from Generation $Y$ and $Z$, educators must evaluate the methods used to educate these young minds while stimulating interest and engagement. While the following methods are not the only methods to consider for a language course, the intention is to review five common methods to promote awareness of the diversity of teaching methods and consider the appropriateness of them with language students in 2017.

1. The Grammar-Translation Method: Richards and Rodgers (2003) explained this method as a focus on written words and meanings, while having little to do with listening or speaking. While this method is useful to the learner in preparation for a career that deals with reading or writing, it is not beneficial for the student who wants conversational practice. This method may please Generation $Y$ and/or Z because students are used to being constantly connected to technology, without being verbally involved in communication. This method would also be useful for an online course in which little involvement is needed from the instructor. Translations of authentic texts could be assigned for homework assignments and then reviewed in class. This method could also help Generation Z students focus on orthography.

2. Natural Method: According to Richards and Rodgers (2003), "Sauveur and other believers in the Natural Method argued that a foreign language could be taught without translation or the use of the learner's native language if meaning was conveyed directly through demonstration and action" (p. 11). Richards and Rodgers (2003) explain that instead of a focus on grammar rules, speaking, demonstration, and interaction is emphasized. This method may frustrate Generation Y or Z students who feel a need to have consistent feedback, yet it could be altered to include a handheld technology tool to use as a reference when needed.

3. Community Language Learning (CLL): According to Richards and Rodgers (2003), CLL, "...combines innovative learning tasks with conventional ones" (p. 93) through translation, group work, recording, transcription, analysis, reflection, listening, and free conversation and critics argue that in addition to long periods of silence while deciding what to talk about, it has a special psychological counselling approach that may require special training. This method may be appropriate for Generation $\mathrm{Y}$, as Tulgan, Baumann, Graham and McDonald (2016) stressed the need for this generation to collaborate.

4. Total Physical Response (TPR): Playing "Simon Says" can be a useful activity in a language classroom, especially for kinesthetic learners. Some educators worry about using only this method because it does not focus on writing and is limited to commands. Richards and Rodgers (2003) described TPR, developed by James Asher, as using commands in the target language to engage students through physical activity. Asher (2000) explained that writing could indeed be integrated into lessons, but most 
interactions are conversational. TPR can allow students to be leaders or followers, depending on who is giving/receiving the commands. It functions well with a partner situation and requiring one person to be in charge, catering to the needs of the Generation $\mathrm{Y}$ and $\mathrm{Z}$ students.

5. Teaching Proficiency through Reading and Storytelling (TPRS): According to Ray and Seely (2009), TPRS builds on James Asher's TPR, but adds a storyline instead of limiting conversations to only commands. This method can combine aspects from all of the aforementioned methods and even integrate technology to appeal to Generation Y and Generation Z. Fisher (2013) describes how TPRS can be modified by adding technology to keep the students connected and engaged through iPod integration. The participants in Fisher's (2013) study were from Generation Z. The results concluded that, "The iPods and the 5-step process allowed the students to be kinesthetically and visually involved while simulating a conversation and practicing listening skills, catering to the variety of student intelligence groups" (p. 270).

\section{COMMON GROUND AND TECHNOLOGY IMPLEMENTATION WITH VARIOUS METHODS}

No matter the technology or method used to educate current students, instruction should be interesting and include elements of surprise. Brookfield (1990) explained, "Students frequently speak of how the most significant episodes in their learning are completely unexpected and take them almost by

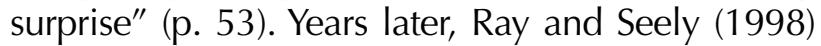
agreed, emphasizing the element of surprise and ironic situations. This element of surprise is essential in language courses to maintain engagement; no matter which method is chosen by the instructor. A monotone lecture does little for new generations of students, as they are accustomed to experiencing constant, surprising, and interesting input in various forms, such as on a Facebook, Vine, or YouTube newsfeed.

In addition to the technology implementation ideas expressed in the previous methods section, basic, current technology to utilize with Generations $Y$ and $Z$ can minimize the amount of paper used and engage students. González-Loret (2015) mentioned that blog spaces such as Blogger, Word Press, Tumblr, SquareSpace, Google+, Hubpages, and Sett can be used with language learners. ToonDoo can also be used with Generation $Y$ and $Z$ students to complement the TPRS method.

Generation Z appreciates creativity and expects engagement. Educators must realize this in order to optimize engagement in the classroom. YouTube utilizes a video function with a comment section to entertain, inform, and educate the population. Vine has a similar concept, yet it shortens the videos to several seconds while utilizing the loop function. Independent learners may find YouTube to be useful to explain grammar topics, especially when the videos can be played multiple times, whereas a lecture in person cannot. Because, as language educators know, frequency is important with all learners, Vine may be a useful tool for students to post videos of them reading a section of a poem in the target language with a creative voice so that the viewers see the video multiple times in a short period of time.

Generation Z students enjoy spending time with technology, but, Geck (2006) explained that this group may not know how to use the technology tools efficiently, resulting in distractions and wasted time. Students need to be monitored with technology to ensure that they are staying on task to maximize productivity. As previously discussed, Generation Z students appreciate staying connected, so allowing them to access technology encourages their personalized education. YouTube, Quizlet, and Prezi are all great examples of online tools that can facilitate language learning. Brünner (2013) highlighted YouTube for current language students and explained how the channels can be particularly useful in a number of languages together with additional tools such as Audacity, Pixton, and Animoto that can facilitate video creations. There are numerous tools that can encourage students to learn a language with technology in a way that captivates their attention, yet it is the duty of the educator to promote these tools and offer support through a process of evaluation and monitoring progress for success. While we cannot use every tool available, just as we cannot use every teaching 
method, educators are encouraged to learn about multiple tools to find a few that may satisfy a specific need for a language course.

\section{ON INSTITUTIONAL CHANGE}

There will always be skeptics present in educational institutions who are intimidated by technology and/ or express no interest in changing their current teaching method, as, in their eyes, it may have worked for them for years in the past. This sentiment discourages any chance for change. Kotter (2012) communicated an eight-stage process of creating major change that can be applied to a variety of needs for change within education. According to Kotter (2012), establishing a sense of urgency, creating the guiding coalition, developing a vision and strategy, communicating the change vision, empowering broad-based action, generating shortterm wins, consolidating gains and producing more change, and anchoring new approaches in the culture are crucial steps to encouraging and following through with change.

Academics with years of experience take pride in their own methods and academic freedom, so implementing a change in teaching method can be a touchy subject. Suppose that an educator shows interest in technology or one of the previous methods and wants to spark change in the teaching methods at an educational institution in order to increase classroom engagement with Generation $Y$ and $Z$, yet there are skeptical colleagues that do not see a need for change, possibly resulting in conflict. The first step in Kotter's (2012) eight-stage process of creating major change is the gateway to showing the educators that there is a need for change. In conflict resolution, finding common ground is imperative, so by realizing that a new method can include aspects of a previous method, it is likely that someone will be open to change. Burns (1978) explained, "...leaders shape as well as express and mediate conflict" (p. 39). Of course, it would be easy to demonstrate a need for change if the scores on proficiency exams were previously not adequate or if one could observe off-task students while glancing in a classroom. A leader must understand the purpose and reasoning behind the need for change. If there is no need for change, then investing time and effort

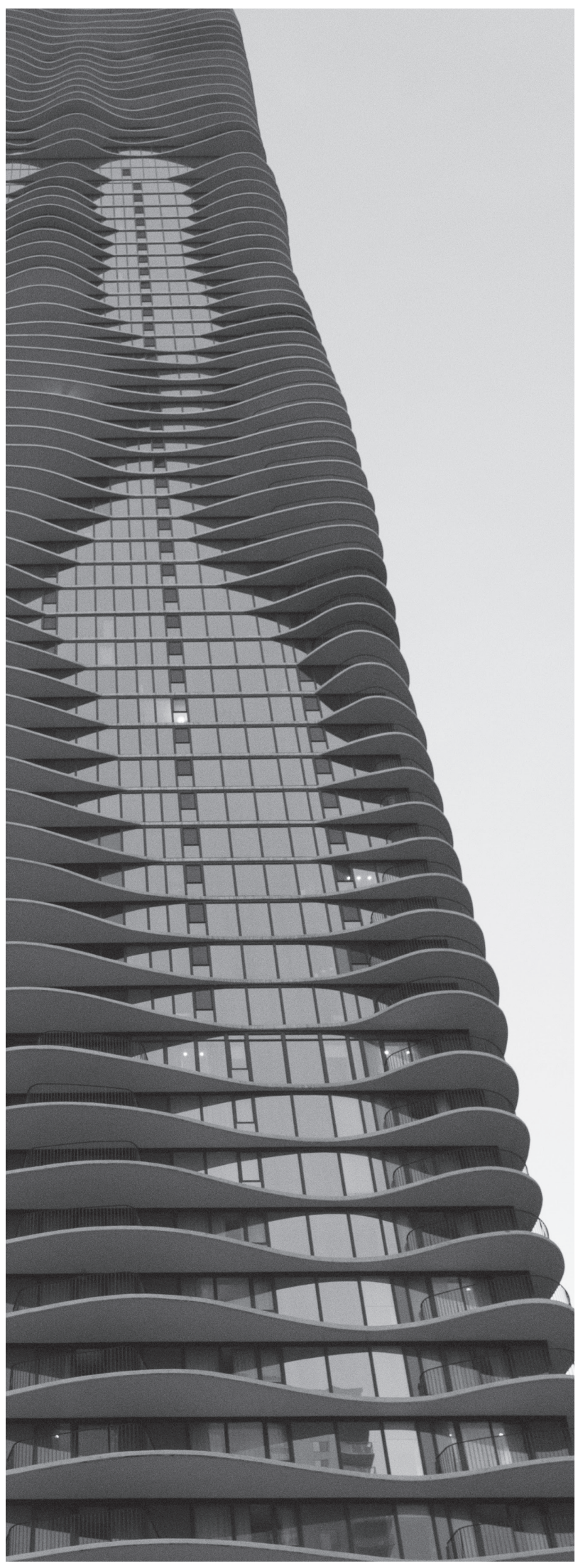

Fotografía de Leonardo Corrales N. 
to provoke change may be a waste of time. This sense of urgency that Kotter (2012) mentioned is an appropriate starting place for implementing change. Once a team effort with mutual understanding and agreement is established, Kotter (2012) encouraged the focus to shift to short-term wins. Showing that a specific technology or method is successful and useful in an educational setting is likely to stimulate and advance the momentum and interest of the initiative.

Regarding technology implementation, Collins and Halverson (2009) explained the skeptic's argument, "Teachers bring many things to learning that computers can never match" (p. 41). This statement displays a sense of fear for technology to replace teachers; however, if a teacher realizes that a technology can make their job easier without diminishing their presence, they may be more open to change. For example, an online platform through a course textbook can significantly reduce the amount of grading for an instructor, increasing the amount of available time to converse with students and plan for engaging lessons. The use of an electronic gradebook can eliminate the hours it takes an instructor to calculate grades. Additionally, using technology such as Blackboard can help the instructor with such aforementioned tasks and also please Generation $Y$ and $Z$ because of the instant and constant feedback. These students enjoy knowing their current average through these options and the instructor does not have to spend time answering emails about grades unless there is a specific question.

\section{CONCLUSIONS}

While it is difficult, if not impossible, to find one method or one technology that pleases everyone, it is possible to learn about multiple options and experiment with change. Should technology be used with language students in 2017? Grgurović, Chapelle, and Shelley (2013) showed that technology use in language classrooms can be as effective as language classrooms that do not utilize technology. The observations of Prensky (2001) and Tulgan, Baumann, Graham and MacDonald (2016) clarify that these students are engaged with technology outside of the classroom and educators are currently experimenting with signs of success, as discussed previously with the findings of Liu, Lan, and Jenkins (2014). Which methods and technologies are appropriate for Generation $Y$ and $Z$ ? The reader is encouraged to consider the five methods discussed previously with current students and technology implementation in mind to reflect on the possibilities of change and improvement in order to foster and increase student interest and engagement. How can change be implemented to increase engagement and participation with Generation Y and Z? Change is not easy for many, yet Kotter's (2012) eight-stage process of creating major change can be a support model for success. Indeed, change is not always necessary, but it may be valid to speculate that the readers of this work are searching for ideas or answers. The aforementioned seven questions regarding technology implementation can also help to promote change and encourage language educators to consider the students of 2017 to maintain interest and engagement.

\section{REFERENCES}

Asher, J. (2000). Learning another language through actions. Los Gatos, California: Sky Oakes Prod.

Brookfield, S. (1990). The skillful teacher. San Francisco: Jossey-Bass Publishers.

Brünner, I. (2013). Using Language Learning Resources on YouTube. ICT for Language Learning. (110-115). Florence, Italy: Pixel.

Burns, J. (1978). Leadership. New York: Harper \& Row. Chaykowski, K. (2016). Facebook No Longer Just Has A 'Like' Button, Thanks To Global Launch of Emoji 'Reactions'. Retrieved from https://www.forbes.com/ sites/kathleenchaykowski/2016/02/24/facebookno-longer-just-has-a-like-button-thanks-to-globallaunch-of-emoji-reactions/\#5ca2e3d2692d.

Collins, A. and Halverson, R. (2009). Rethinking education in the age of technology. New York: Teachers College Press.

Fisher, G. (2013). Taking the next step with TPRS: iPod integration. ICT for Language Learning. Florence, Italy: Pixel.

Geck, C. (2006). The Generation Z Connection: Teaching Information Literacy to the Newest Net Generation. Teacher Librarian, 33 (3), p. 19. 
Gen Z: Digital in their DNA. (2012). JWTIntelligence. Retrieved from http://www.slideshare.net/ jwtintelligence/f-external-genz041812-12653599.

González-Loret, M. (2015). A Practical Guide to Integrating Technology into Task-based Language Teaching. Washington, D.C.: Georgetown University Press.

Grgurović, M., Chapelle, C. and Shelley, M. C. (2013). A meta-analysis of effectiveness studies on computer technology-supported language learning. ReCALL, 25 (02), 165-198.

Kotter, J. (2012). Leading change. Boston, Mass.: Harvard Business School Press.

Koulopoulos, T. \& Keldsen, D. (2014). Gen Z Effect (1 ${ }^{\text {st }}$ ed.). Brookline: Taylor and Francis.

Lantolf, J. and Appel, G. (1994). Vygotskian approaches to second language research. Norwood, N.J.: Ablex Pub. Corp.

Liu, H., Lan, Y. and Jenkins, J. (2014). TechnologyEnhanced Strategy Use for Second Language Vocabulary Acquisition. English Teaching and Learning, 38 (2), 105-132.

National Center for Education Statistics. (2013). Characteristics of Postsecondary Students. Retrieved
28 January 2017, from https://nces.ed.gov/programs/ coe/indicator_csb.asp.

Prensky, M. (2001). Digital Natives, Digital Immigrants Part 1. On The Horizon, 9 (5), 1-6. Retrieved from: https:// doi.org/10.1108/10748120110424816

Ray, B. and Seely, C. (1998). Fluency through TPR storytelling. Berkeley, CA: Command Performance Language Institute.

Ray, B., \& Seely, C. (2009). Fluency through TPR storytelling-Achieving real language acquisition in school. Berkeley, CA: Command Performance Language Institute.

Richards, J. and Rodgers, T. (2003). Approaches and methods in language teaching. Cambridge: Cambridge University Press.

Thorne, S. \& Smith, B. (2011). Second Language Development Theories and Technology-mediated Language Learning. CALICO Journal, 28 (2), 268277.

Tulgan, B., Baumann, K., Graham, B. and McDonald, P. (2016). Get Ready for Generation Z, 1-23. Roberthalf.

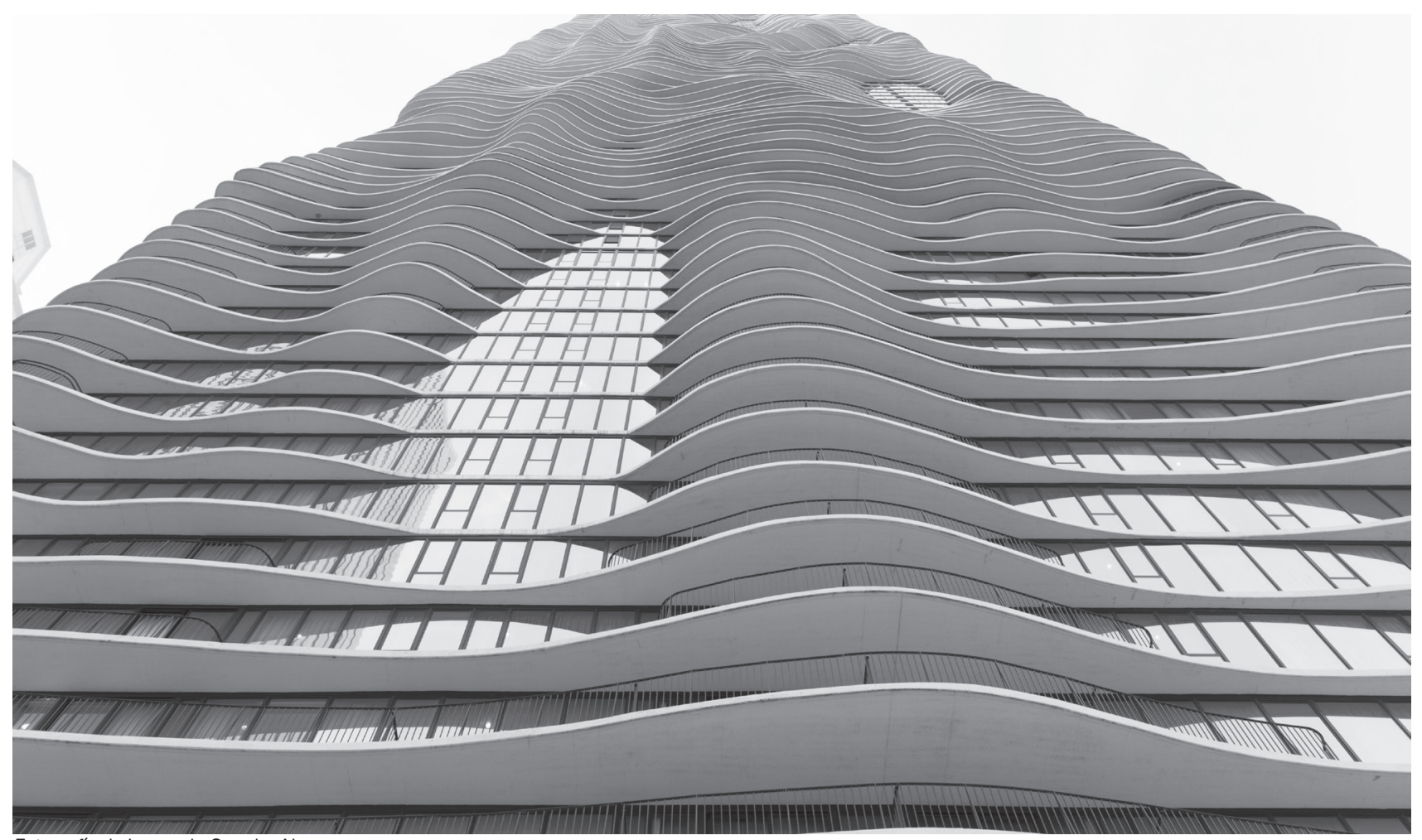

